\title{
VHL wt Allele
}

National Cancer Institute

\section{Source}

National Cancer Institute. VHL wt Allele. NCI Thesaurus. Code C53120.

Human VHL wild-type allele is located within 3p26-p25 and is approximately $10 \mathrm{~kb}$ in length. This allele, which encodes von Hippel-Lindau disease tumor suppressor protein, is involved in the regulation of protein ubiquitination and proteasomal targeting. Mutations in the gene are associated with von Hippel-Lindau syndrome. 